\title{
Подземные резервы Крупнейших городов для развития объектов культуры
}

\author{
А.В.Анисимов, НИИТИАГ, НИУ МГСУ, Москва
}

В перенаселённых центрах крупнейших городов почти не осталось свободных мест для строительства новых объектов культуры и расширения существующих. Наиболее реальные пути дальнейшего развития - использование подземного пространства или внутренних резервов действующих зданий. Но внутренние резервы невелики и быстро заканчиваются. Статья напоминает, что подземное пространство активно использовалось человечеством с начала христианства и в последние два века. Но этот интересный процесс носил стихийный и в основном штучный характер, избирательно освещённый в статье. Несмотря на известные трудности (упомянутые в статье) у подземного развития сети культурных объектов есть богатые перспективы в самых соблазнительных частях города при условии создания упорядоченной системы использования подземного пространства, или «трюма города», как его называет автор. Практика показала, что вторые залы, малые залы, театры-студии, музеи особого вида и ограниченного размера и многие технические и вспомогателные службы могут удобно и безболезненно размещаться в подземном пространстве города.

Ключевые слова: Объекты культуры, подземное пространство, музеи, театры, концертные залы, реконструкция, реставрация, расширение пространства, инженерные коммуникации.

\section{Underground Reserves of the Largest Cities for the Development of Cultural Objects}

A.V.Anisimov, NIITIAG, NIU MGSU, Moscow

In the congested centers of the largest cities, there are almost no free places left for the construction of new cultural objects and the expansion of existing ones. The most realistic way of further development is the use of underground space or internal reserves of existing buildings. But internal reserves are small and run out quickly. The article recalls that the underground space has been actively used by mankind since the beginning of Christianity and in the last two centuries. But this interesting process was spontaneous and mostly piecemeal, selectively highlighted in the article. Despite the known difficulties (mentioned in the article), the underground development of the network of cultural objects has rich prospects in the most attractive parts of the city, provided an orderly system of using underground space or the city's "hold", as the author calls it. The practice has shown that second halls, small halls, studio theaters, museums of a special kind and limited size, and many technical and support services can be conveniently and painlessly located in the underground space of the city.

Keywords: cultural objects, underground space, museums, theaters, concert halls, reconstruction, restoration, expansion of space, engineering communications.

В жестоком языческом Риме не было места для рождающейся новой культуры христианства и она ушла в подземные катакомбы с вертикальными световыми колодцами. Выжила там и победила, заставила могучий Рим сменить свою религию [1]. И над его забытыми могилами поставила великие купола и грандиозные колокольни христианского мира, устремлённые в небо. Там под землёй кроме мест захоронения были и молельные залы, и места для собраний и обучения, и трапезные залы, и места для проповедей и крещения [2]. Так с глубокой древности развивались традиции подземной культуры (рис. 1).

Перегруженные склады, скверные тюрьмы средневековья и грязные мастерские издавна прятали под парадные этажи разных домов (иногда дворцов) в полуподвалы и трюмы города.

В перегруженных центрах крупнейших городов XX века под землю уходят стоянки, дебаркадеры, венткамеры, насосные, обезлюдевшие автоматизированные цеха, а иногда целые вокзалы и транспортные магистрали. Возникает подземный уровень города, удобно связанный с метрополитеном.

B XX веке дело дошло и до объектов культуры. Появились подземные кинотеатры, музеи, книгохранилища и даже театры. Перенасыщенный Париж в конце века умудрился врыть в землю дворы с четырехэтажными офисами, извратив произведение Зерфюса и Нерви под названием Юнеско. Это уже культура, так как Организация Объединенных Наций по вопросам образования, науки и культуры (United Nations Educational, Sientific and Cultural Organization) создана для координации мировой культуры (рис. 2).

Подвалы Гранд Опера стали поводом для буйной фантазии Гастона Леру, создавшего полулегенду про «Призрак Оперы»., что близко к нашей теме. Огромный водоём с противопожарным резервуаром и грунтовыми водами (рис. 3) пригрезился автору и его героям таинственным озером с дачным домиком в подвале, где живёт урод-певец - учитель красавицы-певи- 
цы [3]. А на самом деле эти подвалы недостроенного театра использовали коммунары в 1870 году, чтобы содержать там, допрашивать, убивать и хоронить своих идейных врагов. Кстати, рядом с их костями нашли и скелет, так называемого, «призрака оперы».

В подвалах (дома Перцова, а затем Нирензее) с начала XX века работало популярное в свое время кабаре «Летучая мышь» под эгидой знаменитых мхатовских артистов. Здесь, наоборот, царило веселье и лёгкое искусство, организованное мхатовцем Н. Балиевым. А приходили сюда отдыхать самые серьезные артисты: К.С. Станиславский 0.Л. Книппер, В.И. Качалов, И.М. Москвин и многие другие. Подвал никого не пугал, если бы не наводнение [4]. Подобный подвал был и в Петербурге на Михайловской площади, в котором размещалось кабаре «Бродячая собака». Но в нём хозяевами были поэты-писатели и футуристы. В изменённом виде этот подвал и сейчас пользуется успехом.

Более 15 лет совершенствовался коллектив учеников Олега Табакова в подвале старого жилого дома на улице Чаплыгина. Именно там популярная студия превратилась в известный Московский театр под руководством Олега Табакова, прославила свой фирменный знак - «Табакерку» - и вышла на поверхность столичного города возле Сухаревской площади в чужом доме.

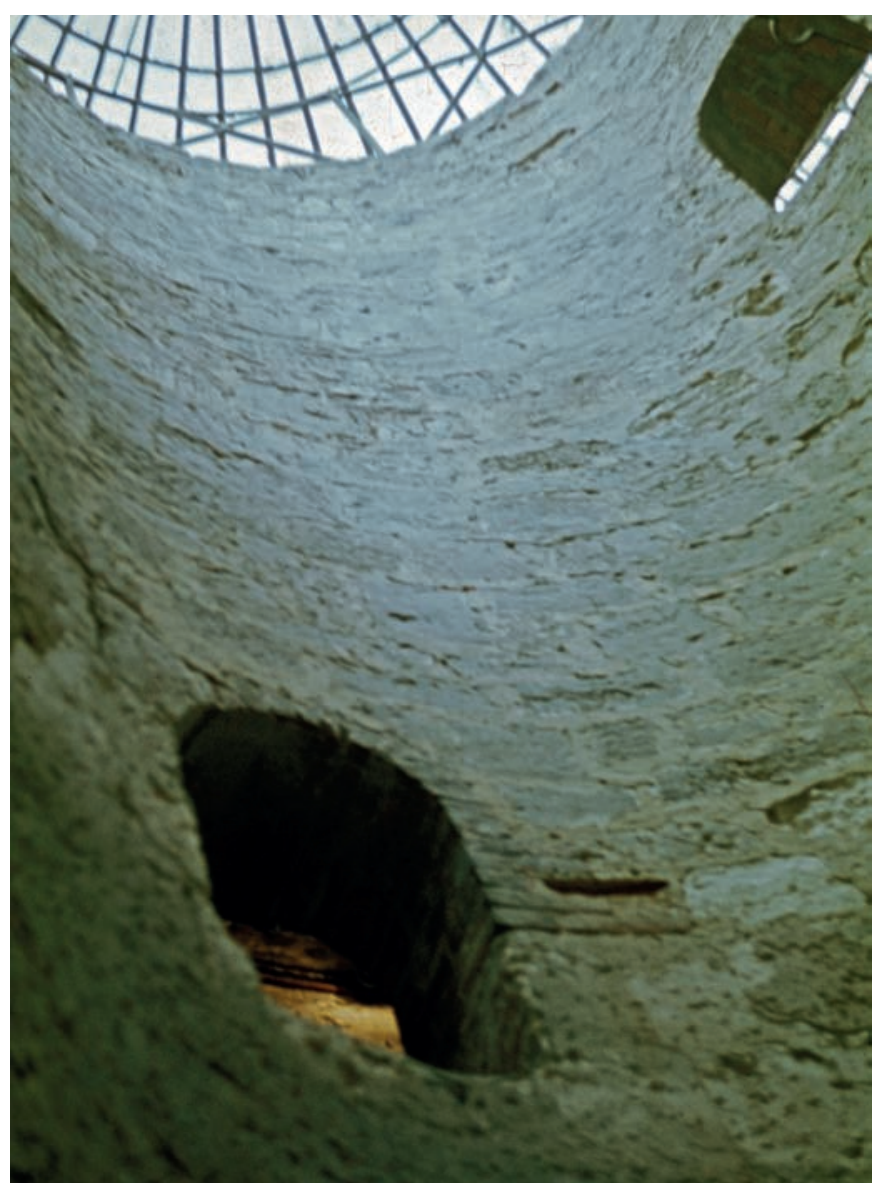

Рис. 1. Катакомбы в Александрии. Световой колодец. Фото A.В. Анисимова
В последнее столетие в крупнейших городах мира всё чаще используется подземное пространство и при новом строительстве, и особенно при реконструкции для расширения площади театров и музеев в привычном для посетителей освоенном районе. Распространены случаи использования морально устаревших и заброшенных технических и транспортных сооружений. Так в конце XX века в Лондоне ненужный тоннель был приспособлен для небольшого театрика. В бывших катакомбах устраивают музеи (Париж) и др. Широко использовались старые бомбоубежища.

Уже почти полвека в Хельсинки существует интересное сооружение - круглая в плане евангелическо-лютеранская церковь Темппелиаукион киркко, вырубленная в скале (1969, архитекторы Тимо и Туомо Суомалайнен). Только плоский купол выступает на поверхность и за счёт рельефа - главный вход (рис. 4). Здание имеет свободный режим использования. В нём часто устраиваются концерты, в том числе и выступления балета, несмотря на церковное предназначение. Верхний свет из под купола и журчание стекающей в специальную пристенную канавку грунтовой воды создают особую атмосферу и настроение зрителям [4].

В послевоенные годы в Москве у развилки Ленинградского шоссе в подвале нового солидного многоэтажного жилого дома был размещён местный кинотеатр «Сокол», зал которого

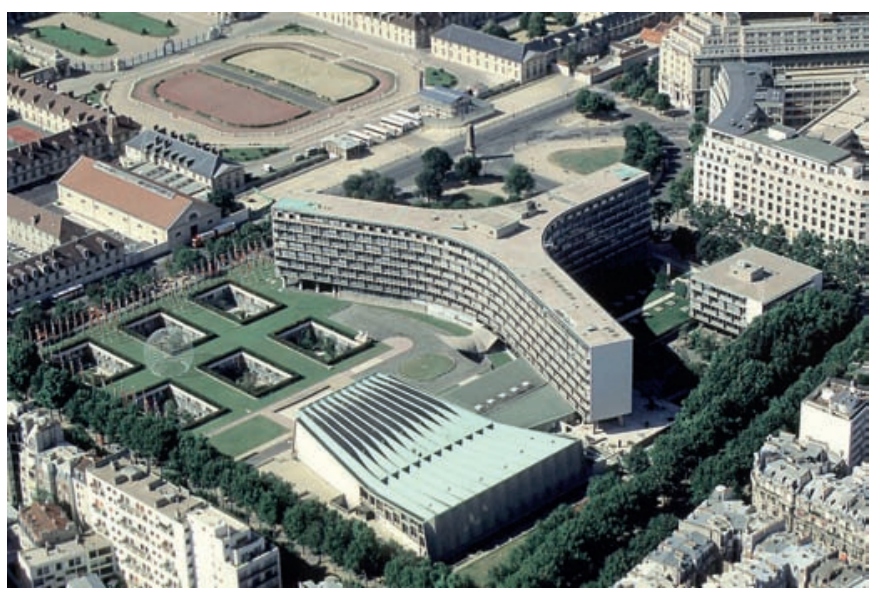

PUс. 2. Подземные дворы с офисами в здании ЮНЕСКО. Париж

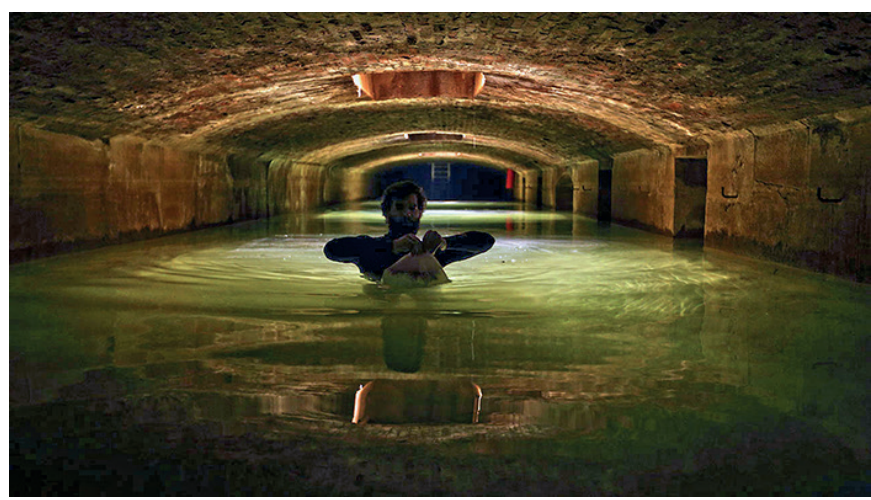

Puс. 3. Подземелье Гранд Опера с водным бассейном - «озеро» из «Призрака Оперы». Париж 
впоследствии с успехом использовал Камерный музыкальный театр под руководством главного режиссера Большого театра Бориса Александровича Покровского. В этом была какая-то особая театральная игра. Конечно, не хватало высоты и не было трюма, но для камерной оперы это не было главным. Здесь царил настоящий творческий накал самого высокого класса.

Довольно давно в оперных театрах - Большом в Москве и Мариинском в Ленинграде - кудовольствию оркестрантов для них в глубоком подвале под зрительным залом оборудовали фойе и места для хранения инструментов, пультов и нот. Я знаю, что музыканты этим были очень довольны и ласково называли эти помещения «наше метро» (рис. 5).

При реконструкции Королевского театра в Лондоне (Ковент Гарден) в самом конце XX века был построен в двух подземных уровнях новый Малый зал, хотя была возможность разместить его в новом здании и выше (рис. 6-8). Это стало распространённым приёмом для камерных театральных организаций, пожалуй, во всём мире. Кинозалы и театры не нуждаются в дневном освещении при хорошей вентиляции и надежных путях эвакуации безболезненно живут в «новых катакомбах», иногда, с интересными интерьерами.

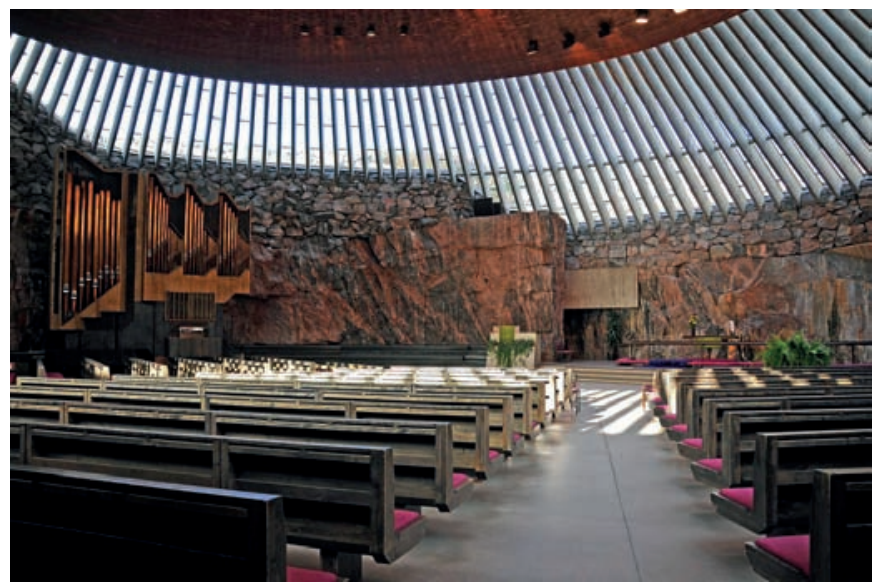

Рис. 4. Церковь Темппелиаукио (Tетрреliaukio-Church), врезанная в скалу. Хельсинки, Финляндия
В 1970-х годах в Париже при Центре Жоржа Помпиду был создан Институт по изучению и координации музыкальной акустики (Institut de Recherche et Coordination Acoussstique Musique - IRCAM). На соседней с Центром площади перед боковым фасадом церкви Сен-Мерри под площадью Игоря Стравинского (рис. 9) с водоёмом архитекторы Ренцо Пьяно и Ричард Роджерс разместили под землёй экспериментальный зал этого Института. Тонкие акустические исследования в зале с трансформируемыми акустическими панелями на стенах и потолке требовали идеальной изоляции от городских шумов. Именно это обеспечивало подземное размещение зала с устройством над ним водного бассейна - своего рода акустической подушки. Помещение размером 25×17 м имеет высоту 15 м. Бетонные поверхности покрыты панелями с треугольными поворотными призмами. Каждая сторона треугольника имела поверхность с разной степенью отражения и поглощения звука. Подвижной потолок мог опускаться и подниматься образуя разную конфигурацию подвесного ограждения. В проекте и пол мог менять свою конфигурацию. Этот подземный зал работает уже более четырёх десятилетий - с 1977 года (рис. 10-11), это «исследовательская организация, созданная по поручению Жоржа Помпиду композитором Пье-

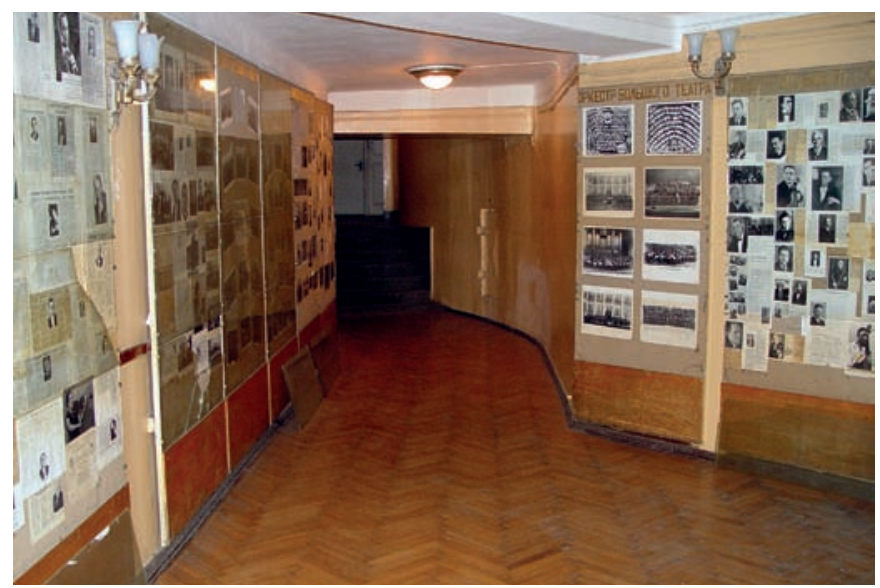

Рис. 5. Большой театр. Подземная рекреация и фойе оркестрантов. Фото А.В. Анисимова. Июнь 2005 года, перед началом реконструкции

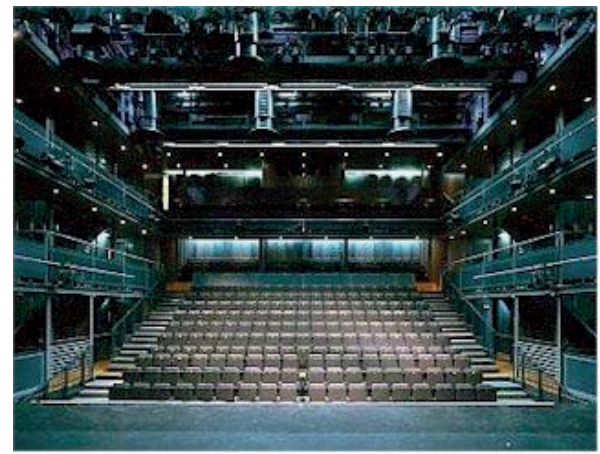

a)

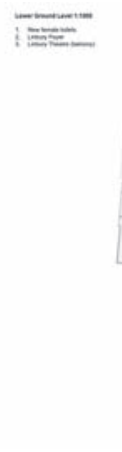

б)

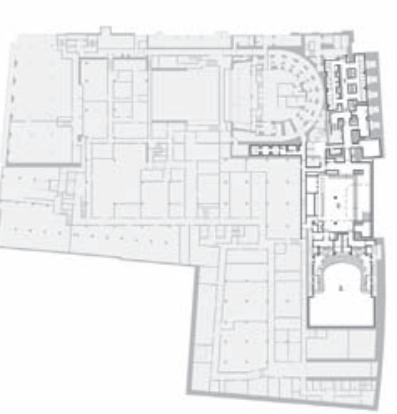

B)

Рис. 6. Новый Малый зал Королевского театра Ковент Гарден: а) общий вид зрительного зала; б) план 1-го подземного этажа с Малым залом; в) план 2-го подземного этажа. Малый зал 


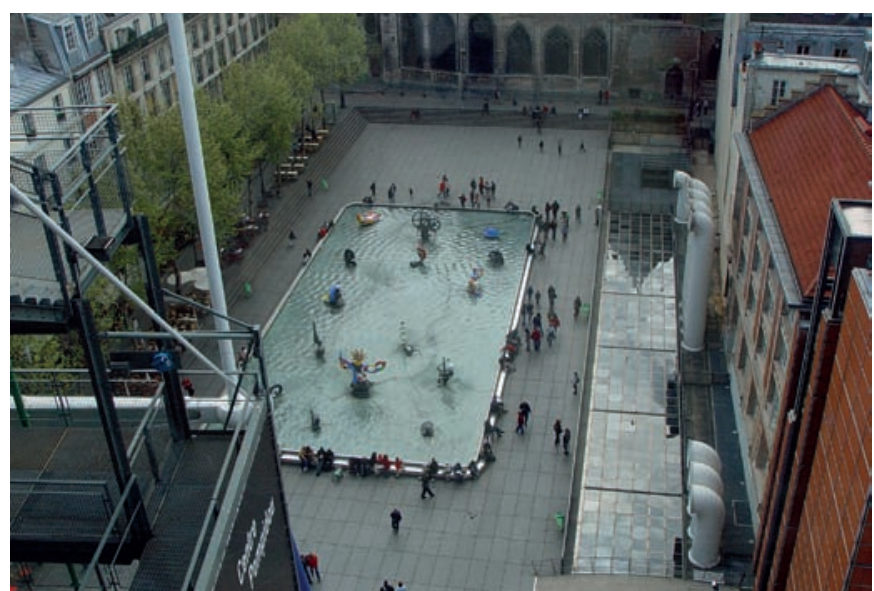

Рис. 9. Париж. Площадь Игоря Стравинского, под которой зал Института по изучению и координации музыкальной акустики - ИРКАМ (IRCAM). Фото А.В. Анисимова

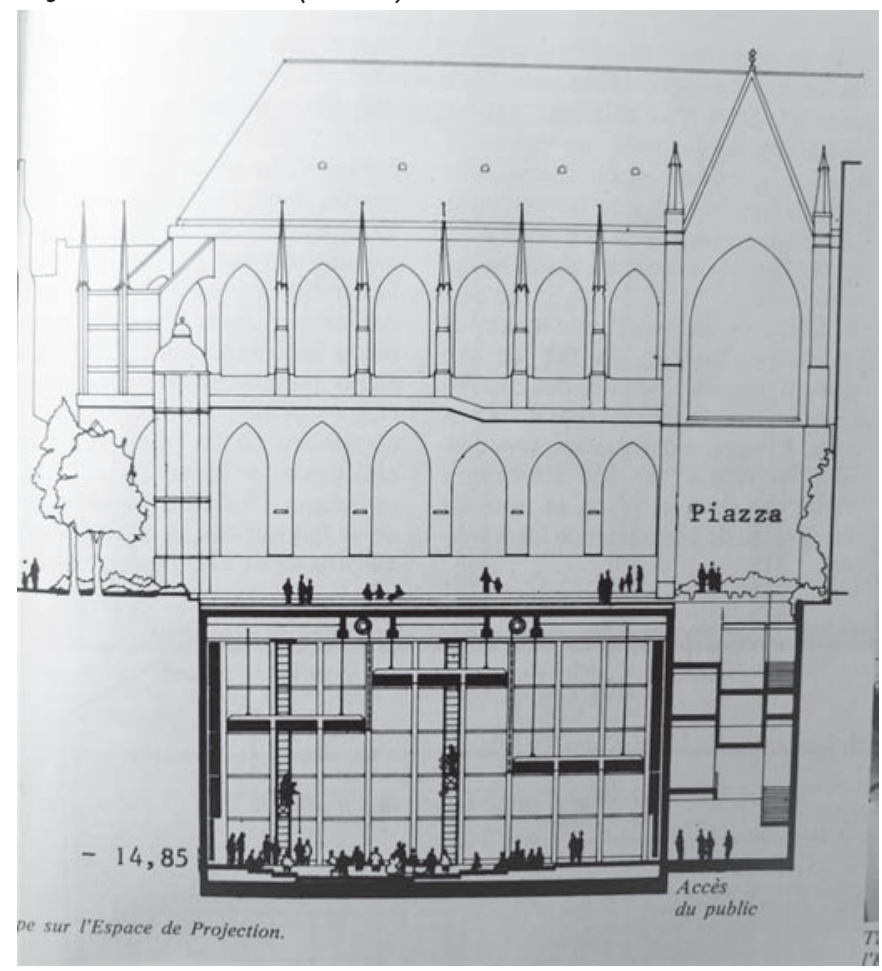

РUс. 10. Разрез зала IRCAM

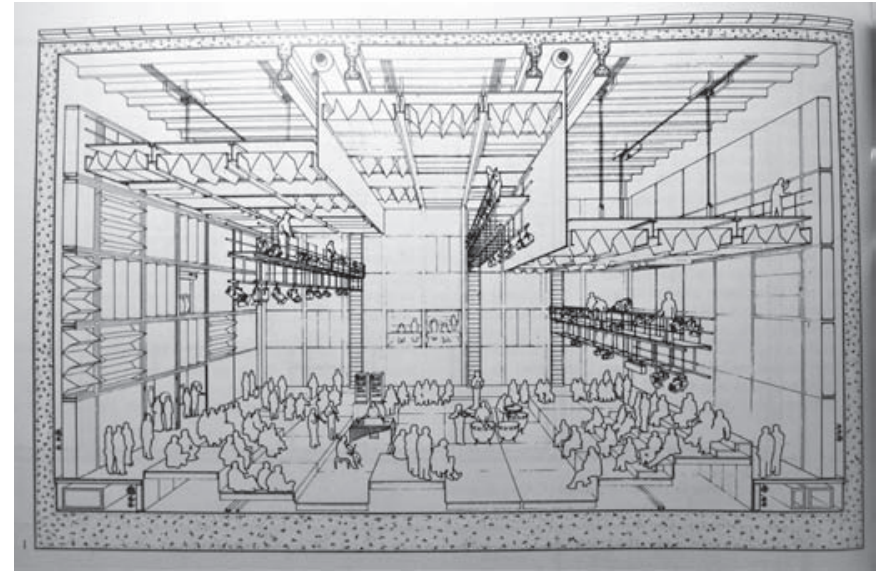

Рис. 11. Общий вид интерьера зала IRCAM по проекту ром Булезом для современных музыкальных и музыковедческих исследований. Институт, ассоциированный с Центром Жоржа Помпиду, открылся в 1977» [7]. При увеличении потоков посетителей в наши крупнейшие музеи и страшном дефиците в них вестибюльных площадей в Русском музее, в Третьяковской галерее, частично в Музее изобразительных искусств и даже в Государственном Эрмитаже (там не запускали, а выпускали когда-то через подвальный выход на Дворцовую набережную) жаждущий искусства народ стали запускать через подвалы. В результате реконструкции в полуподвалах оборудовали просторные гардеробы, туалеты, места для отдыха и встреч, и даже книжные ларьки. Конечно, раздрожало, что при наличии шикарных парадных входов людей пускали через крохотную дверь, ведущую в полуподвал, но это был выход из положения. Он подсказывал будущим градостроителям, как в перенаселённых центрах мегаполисов с обилием ценной исторической застройки можно радикально и с комфортом увеличить площади раразвивающихся объектов культуры, не выталкивая их на перефирию города и не нарушая сложившиеся ансамбли. Но всё же это было вынужденное решение. И всегда чувствовалось, что Русский музей находится в приспособленном для него здании. Но здорово приспособленном в великолепном здании великого Росси. И это намного лучше, чем специально построенный Клейном Музей изящных искусств с ущербным гардеробом и буфетом.

А вот при реконструкции Лувра использование большого глубокого подземного пространства с престижным главным входом под стеклянной пирамидой автор Йо Минг Пей в 1989 году к 200-летию Великой Французской революции виртуозно превратил в новый неповторимый торжественный вход с огромной площадью рекреационных, сервисных и вспомогательных помещений в нескольких уровнях. Это стало совершенно новым качественным решением, которое заставило навсегда забыть старые громоздкие и неудобные входы этого великого музея (рис. 12-14). Приспособленный для галереи дворец сразу превратился в как бы специально созданный музейный комплекс с богатейшей исторической экспозицией (например, раскопки крепости Филиппа II Августа, зал Людовика Святого и др.). «Самый большой королевский дворец Европы стал величайшим музеем мира» [6].

Конечно, самое радикальное использование подземного пространства для театра было осуществлено при последней реконструкции Большого театра России в 2005-2011 годах. Это было особенно важно, так как основным условием реконструкции было сохранение облика этого памятника архитектуры и реставрация его фасадов и интерьеров зрительской части.

Четырёх подаренных Большому театру зданий на Театральной площади оказалось мало, и он углубился на пять-шесть этажей в московскую не очень подходящую для этого землю недалеко от правого берега убранной под землю реки Неглинки. Освоение многоэтажного подземного пространства позволило полностью перестроить и осовременить всю 


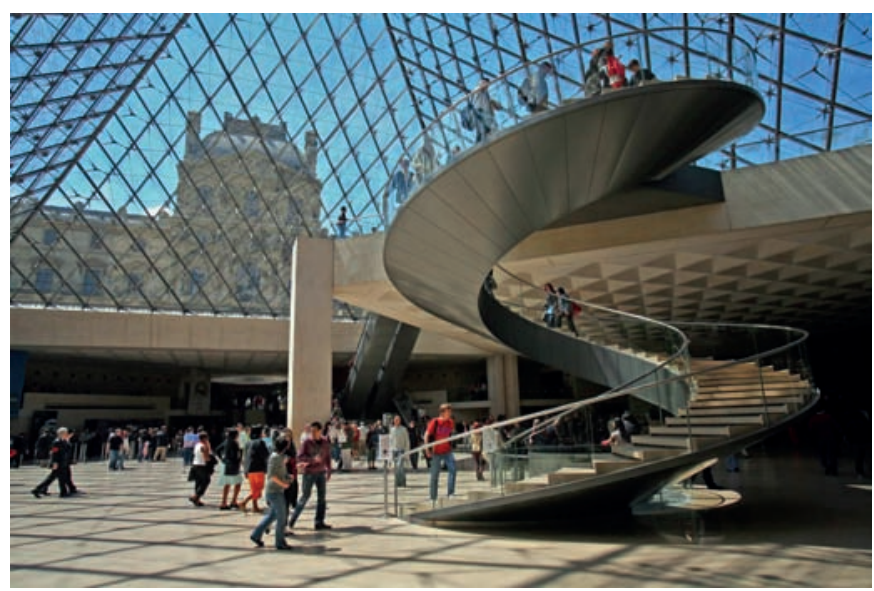

Рис. 12. Подземный вестибюль музея Лувр. -1-ый уровень

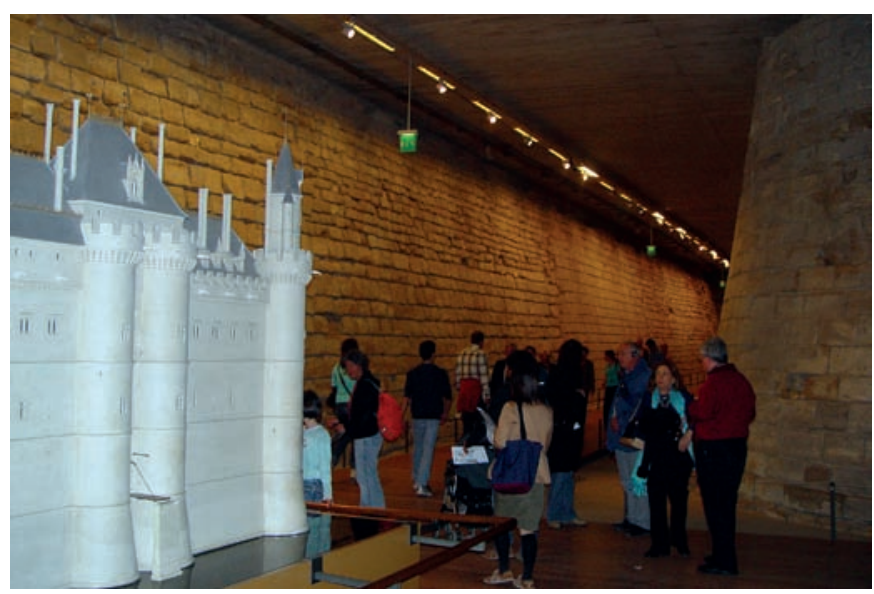

Рис. 13. Подземная археологическая экспозиция древнего Лувра. Фото А.В. Анисимова

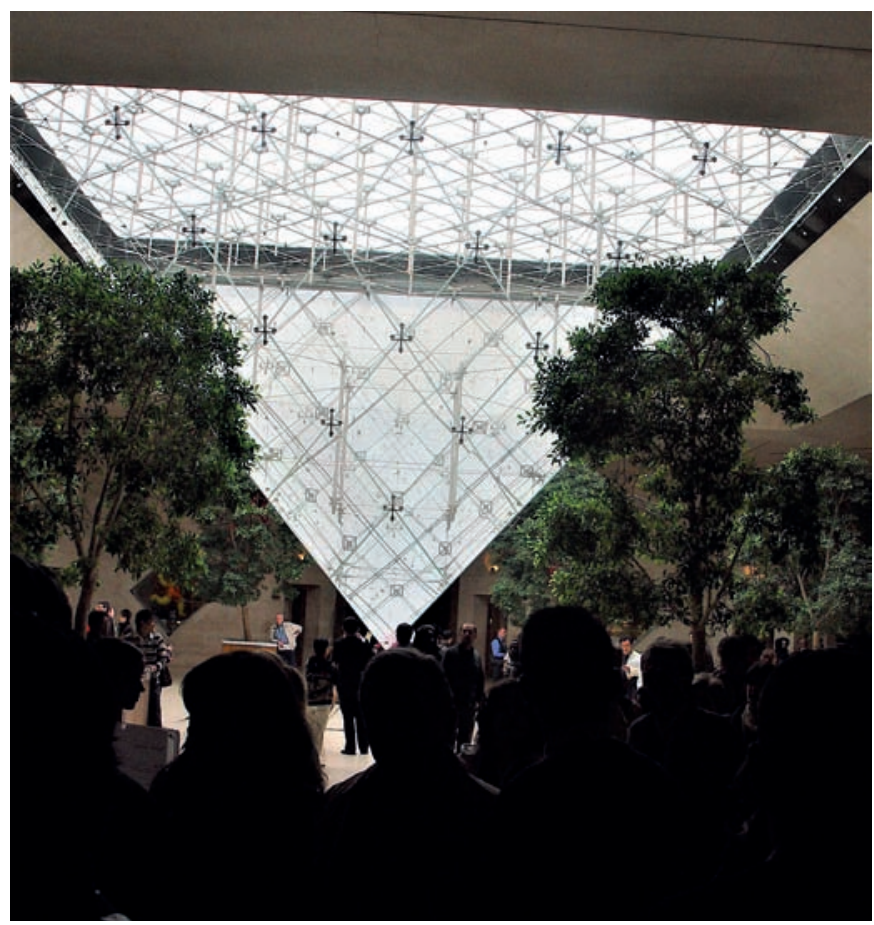

Рис. 14. Рекреация у выхода со световой перевёрнутой пирамидой. Фото А.В. Анисимова

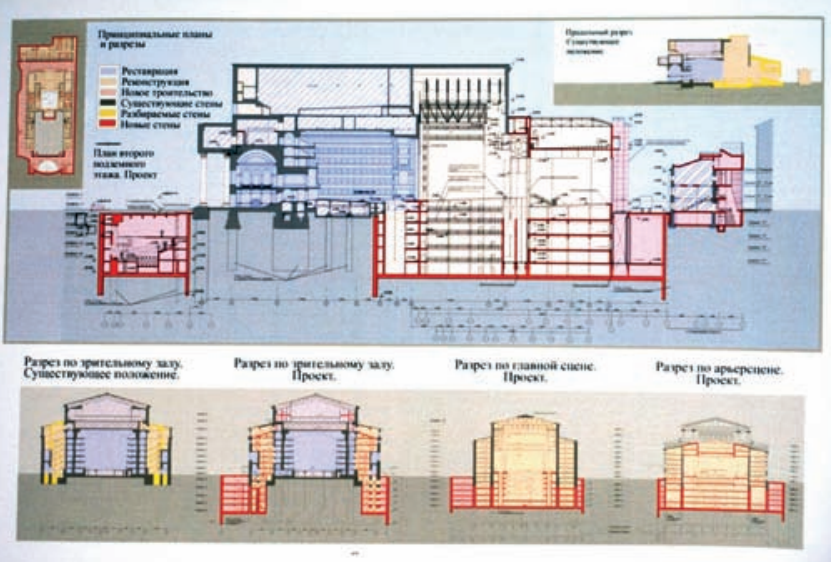

Рис. 15. Большой Театр России. Схемы размешения подземных помещений

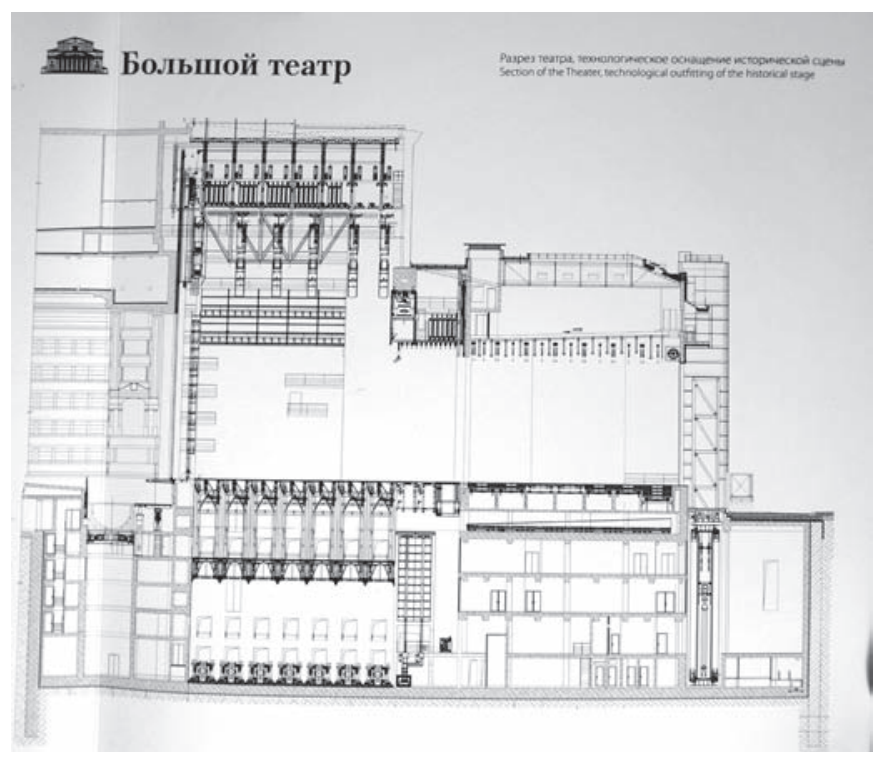

Рис. 16. Схема разреза по сценической части театра (оркестр, сцена с трюмом, аръерсцена склады декораций, грузовой лифт для декораций)

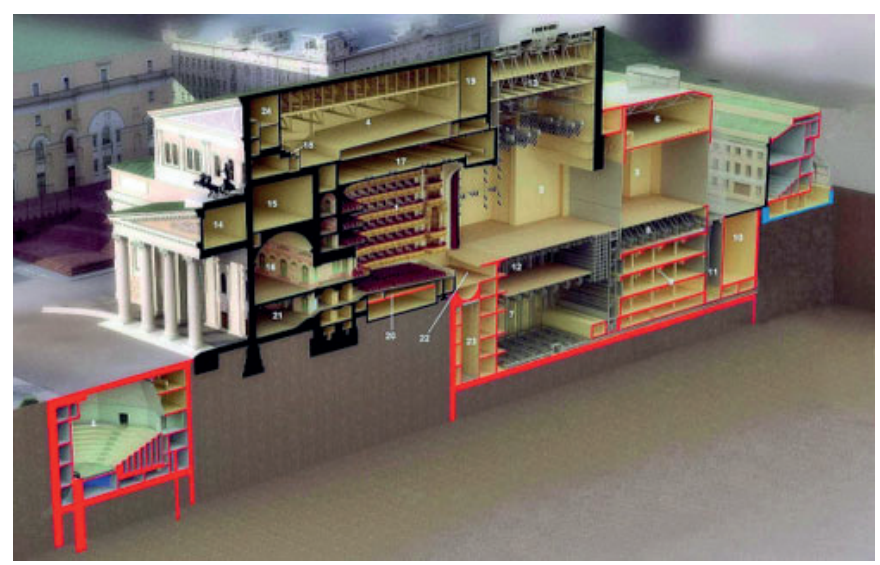

Рис. 17. Разрез по театру с выделением подземной новой части. Макет 
сценическую технологию театра с устройством передвижного балетного планшета и подъёмно-опускного оркестра, разместить большие декорационные склады с огромным суперлифтом (с кабиной 20,25×4,20 м при высоте кабины в 12,5 м) у заднего фасада (рис. 15-17), просторные мастерские, технические и служебные помещения [8]. За пределами исторического здания (перед портиком) под площадью был построен трансформируемый репетиционно-концертный зал со своими гардеробами, туалетами, лифтами и эскалаторами, уходящими в подземное пространство (рис. 18-20). Для этого

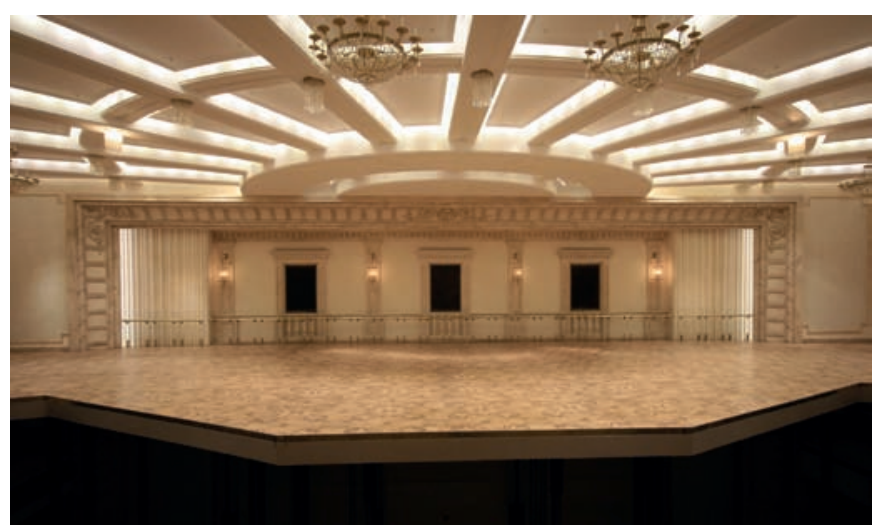

Рис. 18. Репетиционно-концертный зал под площадью. Процесс трансформации. Фото А.В. Анисимова

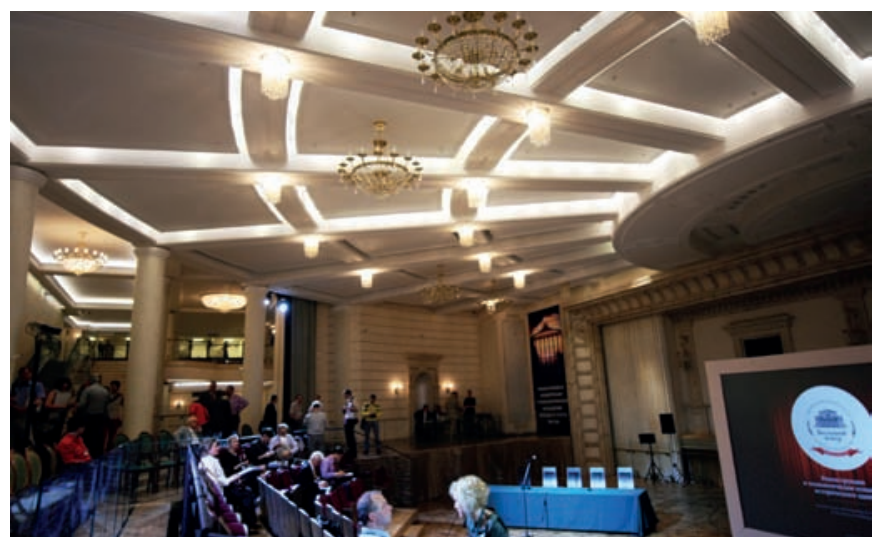

Рис. 19. Вариант трансформации с амфитеатром для концертов и собраний

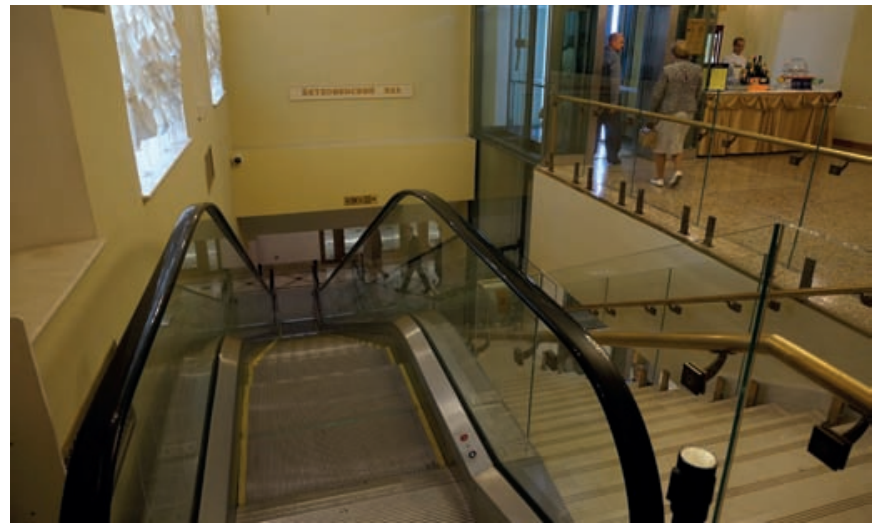

Рис. 20. Эскалатор, лестница и лифт для обслуживания подземного Бетховенского зала зала на краю сквера пришлось сделать два симметричных эвакуационных противопожарных выхода с прозрачными стеклянными стенками [9].

В свое время до разработки рабочихчертежей авторами была предложена Концепция вновь создаваемого подземного пространства ГАБТ [8], которая и реализовалась в 2005-2011 годах.

В театральных сооружениях - новых и реконструируемых - уже сложилась традиция размещать ниже уровня земли определенные помещения: гардеробы, туалеты, камеры кондиционирования, склады, иногда мастерские, малые залы и другие вспомогательные помещения и, конечно, сценические трюмы и оркестровые помещения. Всё это давно вошло в обычную практику. Но в настоящее время, когда центры крупнейших городов перегружены ценными постройками, потоками автомобилей и пешеходов, всё заманчивее выглядит возможность размещения в подземном пространстве целых театров, концертных залов и музеев с их основными помещениями (рис. 22-23). Все эти учреждения мечтают быть в центре именно перегруженного людьми столичного города. И пока что для этого ещё есть возможности. Романтика подвалов особенно соблазнительна для камерных

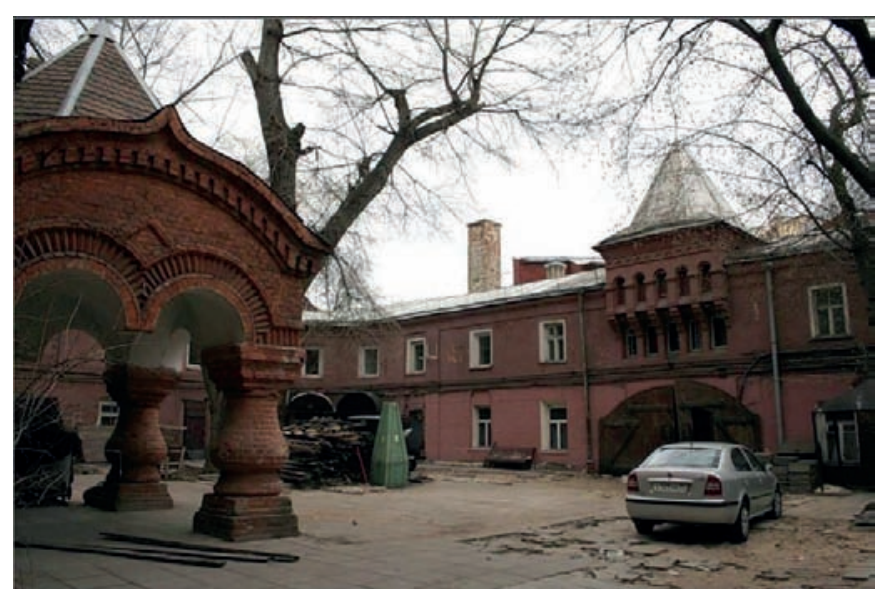

Рис. 22. «Геликон-опера» до реконструкции. Крыльцо во дворе. Фото А.В. Анисимова

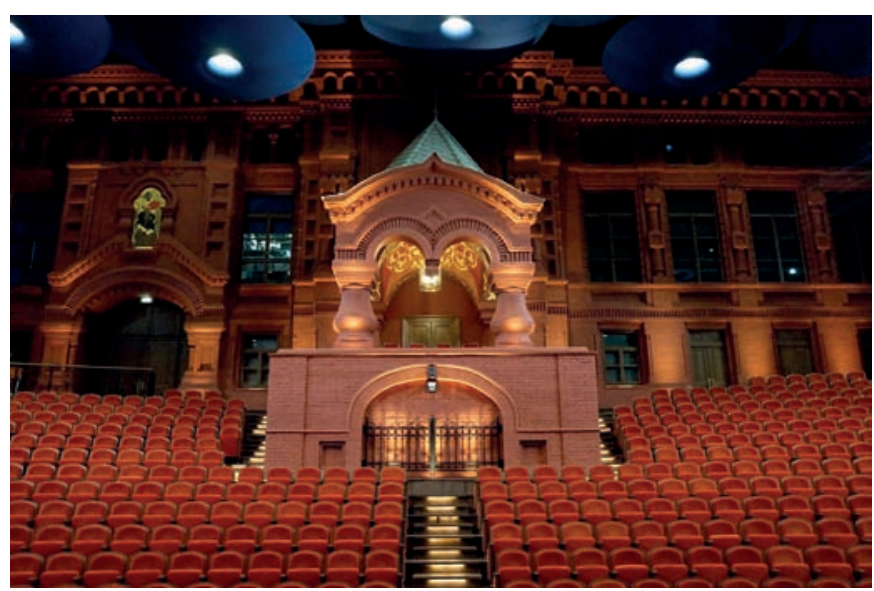

Рис. 23. «Геликон-опера» после реконструкции. Крыльцо стало ложей в заглублённом под землю залом. Фото А.В. Анисимова 
небольших учреждений. Стоит это дорого, но за комфорт и ценное местонахождение в городе приходится платить.

Следует осознавать, что в подземной жизни и при строительстве именно в центрах крупнейших городов есть свои серьёзные трудности. Главная из них - наличие высокого уровня грунтовых вод. В наше время опытные инженеры научились бороться с этой неприятностью. Делают так называемые стены в грунте, оборудуют водонепроницаемые «кастрюли» и в них строят новые помещения. Но надёжность этих работ заказчику и даже архитектору не всегда известна. Помним, что наводнение 1966 года во Флоренции обернулось для цокольных этажей национальной катастрофой.

Другая дорогая работа и иногда непреодолимая сложность - необходимость перекладки городских инженерных коммуникаций и наличие новых транспортных тоннелей и трасс метрополитена мелкого заложения. Эти не переложишь. Более того, шум и вибрация от них требуют значительного удаления и специальной изоляции, особенно для музыкальных залов и звукозаписывающей аппаратуры. Я столкнулся с этим при реконструкции Московского планетария. Вибрация от метрополитена, незаметная для человека, оказывает влияние на основание под обсерваторией и непосредственно на отдельный фундамент под телескопом, направленным на далекие звезды. При космических расстояниях самая

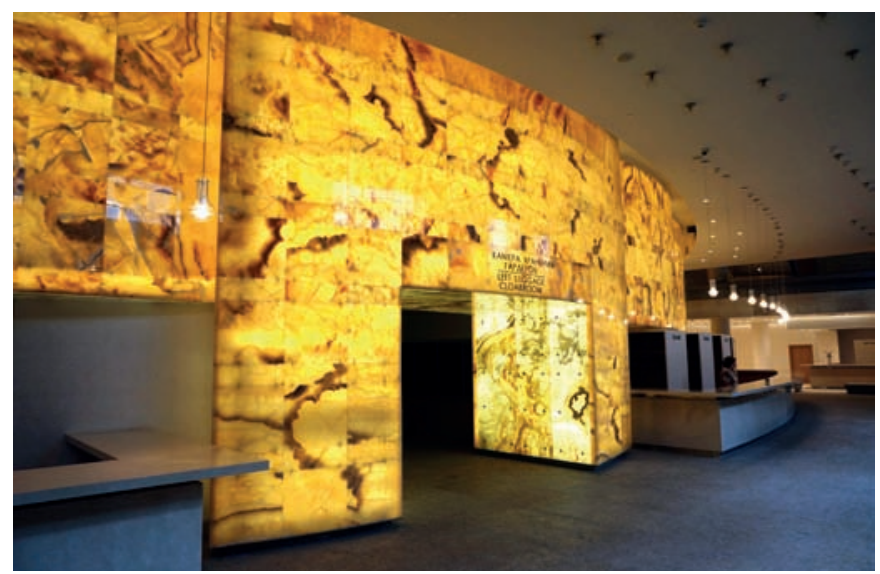

a)

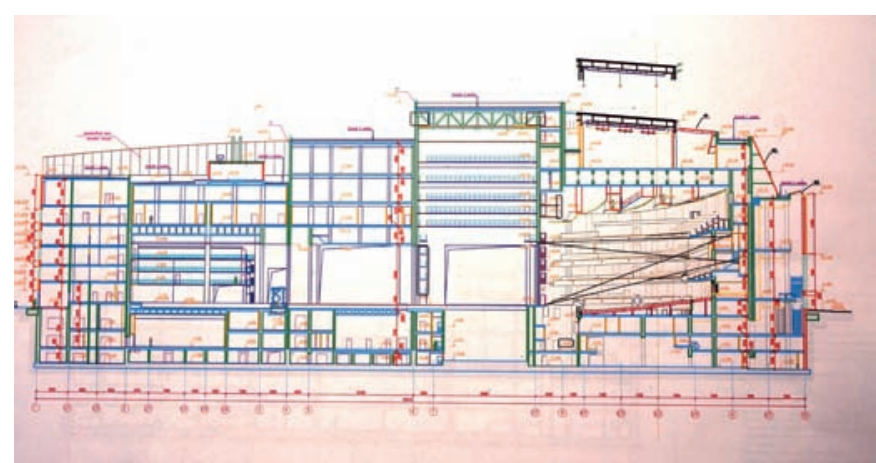

б)

Puc. 24. Новое здание Мариинского театра: а) цокольный этаж сгардеробом и камеройхранения. Фото А.В. Анисимова; б) схема разреза с подземной частью ничтожная вибрация, незаметная для человеческого вестибулярного аппарата, нарушает серьезную работу телескопа и портит изображение.

Психологическое отсутствие естественного дневного света - тоже проблема.

Древние в катакомбах научились с ней бороться, делая вертикальные шахты с прозрачным куполом, строя расходящиеся от них галереи. Но сейчас есть более совершенные способы с использованием зеркал и аппаратурой, подобной перископам с подводных лодок.

Следует учитывать, что в подземных залах требуется особая и надёжная вентиляция. Есть сложности и с канализацией глубоких подвалов, которые решаются устройством станций перекачки.

И всё же, несмотря на все эти сложные и вероятно дорогие работы, освоение подземного пространства объектами культуры в перегруженных центрах миллионных городов оправдано и перспективно. Есть удачные примеры и в новом строительстве и при развитии существующих объектов (рис. $24,25)$. Но удача возможна только при высококачественном выполнении всех работ (от проекта до отделки интерьеров), как это сделано в парижском Лувре, с размахом и не жалея средств, которые при умном подходе окупаются. Под землёй отопление дешевле. Будущее за многоэтажными центрами

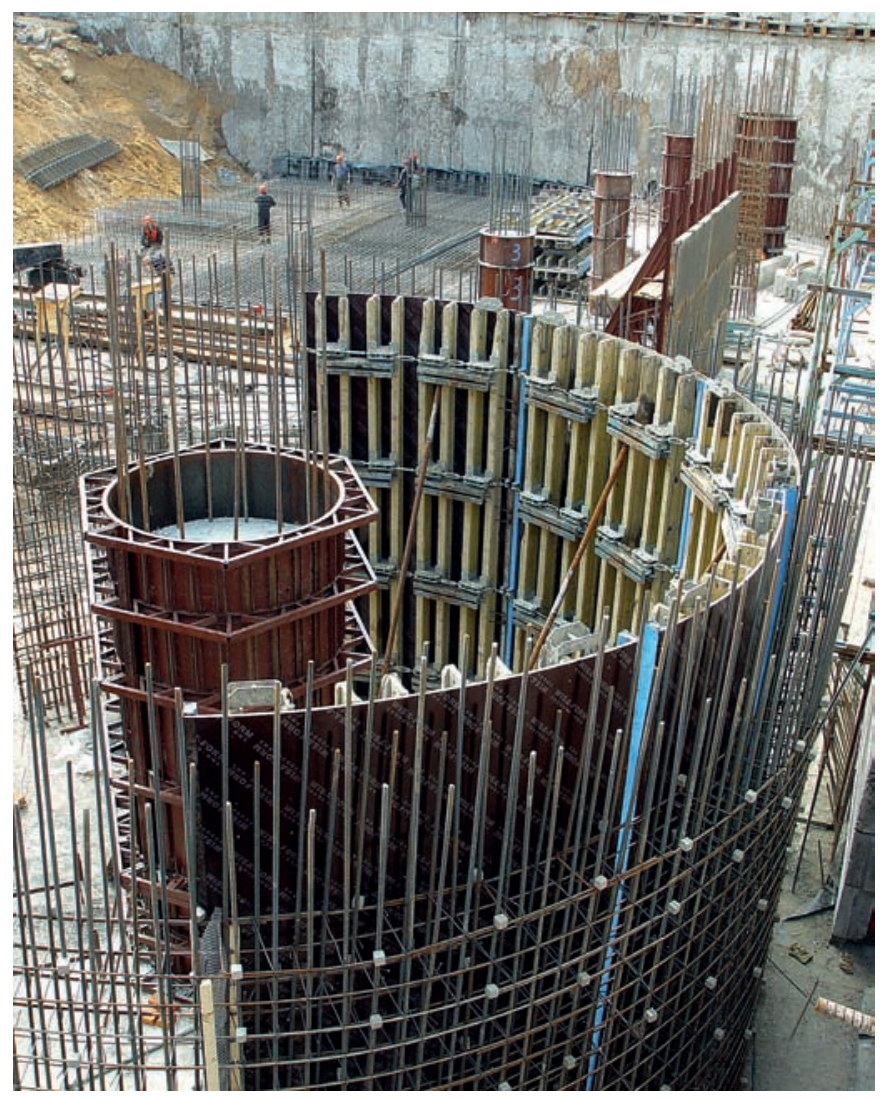

Рис. 25. Процесс создания подземного мира смузеем, стоянкой, рестораном, мастерскими и т.п. при реконструкции Московского планетария. Фото А.В. Анисимова. 2002 год, стройка 
мегаполисов, растущих не только вверх, но и вниз. Может быть там и родится обновлённая христианская культура, как это случилось в катакомбах Рима и Александрии (см. рис. 1).

Процесс этот уже активно идёт в разных странах. Появилась целая серия «музеев-бункеров», залов разнообразного назначения, археологических музеев на базе интересных раскопок. Но в основном это отдельные объекты не связанные друг с другом, реализация которых идёт с большим трудом - от случая к случаю. Для создания рациональной структуры использования «городского трюма» для объектов культуры нужна какая-то система вертикального зонирования с делением между пещеходными переходами, инженерными коммуникациями, транспортными сооружениями с резервированием места и для объектов культуры с романтическим оттенком таинственного подземелья. Многие из них мечтают быть в пекле городской жизни, надеясь на бурное процветание.

\section{Лumepamypa}

1.Stützer, Herbert Alexander. Die Kunst der römischen Katakomben /, Herbert Alexander Stützer. - Köln : DuMont Verlag, 1983. ISBN 3-7701-1485-X

2. Катакомбы Рима [Электронный ресурс] // Википедия. - Режим доступа: https://ru.wikipedia.org/wiki/\%D0\%9A\%D0\%B0\% D1\%82\%D0\%B0\%D0\%BA\%D0\%BE\%D0\%BC\%D0\%B1\%D1\%8B_\% D0\%A0\%D0\%B8\%D0\%BC\%D0\%B0 (дата обращения 06.01.2021).

3. Леру, Гастон. Призрак оперы / Гастон Леру; перевод с французского - М. : Эксмо, 2011.

4. Темппелиаукио [Электронный ресурс] // Википедия. Режим доступа: https://ru.wikipedia.org/wiki/\%D0\%A2\%D0\%B5 $\% \mathrm{DO} \% \mathrm{BC} \% \mathrm{DO} \% \mathrm{BF} \% \mathrm{DO} \% \mathrm{BF} \% \mathrm{D} 0 \% \mathrm{~B} 5 \% \mathrm{D} 0 \% \mathrm{BB} \% \mathrm{DO} \% \mathrm{~B} 8 \% \mathrm{D} 0 \% \mathrm{~B} 0 \%$ D1\%83\%D0\%BA\%D0\%B8\%D0\%BE (дата обращения 06.01.2021).

5. Эфрос, Н.Е. Театр «Летучая мышь» Н.Ф.Балиева / Н.Е. Эфрон. - М., 1913.

6. Тиллер, А. Париж : иллюстрированный путеводитель / А. Тиллер. - М. : АСТ, Астрель,2002. - 433 с.

7. IRCAM // L`Architecture D`Aujourd`hui. - 1978. - № 199. - P. 53-63.
8. Шангин, Н.Г. Пояснительная записка к Проекту 2-ой очереди реставрации и реконструкции комплекса зданий Государственного академического Большого театра России. Том 2 / Н.Г. Шангин. - М., 2005.

9. Анисимов, А.В. Театральные здания Москвы / А.В. АНисимов. - М. : Курс, 2017. - 381 с.

\section{References}

1.Stützer Herbert Alexander. Die Kunst der römischen Katakomben. Köln, DuMont Verlag, 1983. ISBN 3-7701-1485-X

2. Katakomby Rima [Catacombs of Rome]. Vikipediya. Access mode: https://ru.wikipedia.org/wiki/\%D0\%9A\%D0\%B0\%D1\%82 $\% \mathrm{D} 0 \% \mathrm{~B} 0 \% \mathrm{D} 0 \% \mathrm{BA} \% \mathrm{D} 0 \% \mathrm{BE} \% \mathrm{D0} \% \mathrm{BC} \% \mathrm{DO} \% \mathrm{~B} 1 \% \mathrm{D} 1 \% 8 \mathrm{~B} \_\% \mathrm{D0} \% \mathrm{AO}$ $\%$ D0\%B8\%D0\%BC\%D0\%B0 (Accessed 01/06/2021).

3. Leru Gaston. Prizrak opery [The Phantom of the Opera], trans. from French. Moscow, Eksmo Publ., 2011.

4. Temppeliaukio. Vikipediya. Access mode: https:// ru.wikipedia.org/wiki/\%D0\%A2\%D0\%B5\%D0\%BC\%D0\%BF\%D0 $\%$ BF $\%$ D0 \%B5\%D0\%BB\%D0\%B8\%D0\%B0\%D1\%83\%D0\%BA\%D0 $\% B 8 \%$ D0\%BE (Accessed 01/06/2021).

5. Efros N.E. Teatr «Letuchaya mysh'» N.F.Balieva [N.E. Baliev's theater"The Bat"]. Moscow, 1913.

6. Tiller A. Parizh : illyustrirovannyi putevoditel' [Paris: an illustrated guide]. Moscow, AST, Astrel' Publ., 2002. - 433 p.

7. IRCAM. Dans: L` Architecture D`Aujourd`hui, 1978, no. 199, pp. 53-63.

8. Shangin N.G. Poyasnitel'naya zapiska k Proektu 2-oi ocheredi restavratsii i rekonstruktsii kompleksa zdanii Gosudarstvennogo akademicheskogo Bol'shogo teatra Rossii. Tom 2 [Explanatory note to the Project of the 2 nd stage of restoration and reconstruction of the complex of buildings of the State Academic Bolshoi Theater of Russia. Volume 2]. Moscow, 2005.

9. Anisimov A.V. Teatral'nye zdaniya Moskvy [Theater buildings of Moscow]. Moscow, Kurs Publ., 2017, 381 p.

Анисимов Александр Викторович (Москва). Доктор архитектуры, член-корреспондент РААСН, академик МААМ. Профессор ВГИК и МГСУ, главный научный сотрудник филиала ФГБУ «ЦНИИП Минстроя России» Научно-исследовательского института теории и истории архитектуры и градостроительства (111024, Москва, ул. Душинская, 9. НИИТИАГ). E-mail: alexandranisimo@ yandex.ru; anisimov1935@gmail.com.

Anisimov Alexander V. (Moscow). Doctor of Architecture, Corresponding Member of RAACS, Academician of IAAM. Professor of VGIK and MGSU, Chief Scientific Officer of the Research Institute of Theory and History of Architecture and Urban Planning (9 Dushinskaya st, Moscow, 111024. NIITIAG), branch of the Central Institute for Research and Design of the Ministry of Construction and Housing and Communal Services of the Russian Federation (TsNIIP).E-mail: alexandranisimo@yandex.ru; anisimov1935@ gmail.com. 